\title{
Impact of chronic schistosomiasis and HBV/HCV co-infection on the liver: current perspectives
}

This article was published in the following Dove Press journal:

Hepatic Medicine: Evidence and Research

\section{Hanan Hassan Omar}

Clinical Pathology Department, Faculty of Medicine, Suez Canal University, Ismailia, Egypt
Correspondence: Hanan Hassan Omar Clinical Pathology Department, Faculty of Medicine, Suez Canal University, Ismailia 4 IIII, Egypt

Tel +201093627403

Email hananhassan1978@gmail.com

\begin{abstract}
Schistosomiasis is a public health problem in many countries. Its prevalence is increasing annually; the current infection rate is one in 30 individuals. The WHO reported that at least 206.4 million people all over the world required preventive treatments for schistosomiasis in 2016. Chronic schistosomiasis, hepatitis B virus (HBV) and hepatitis C virus (HCV) co-infection are common in countries where schistosomiasis is endemic. The effects of the hepatotropic virus co-infection may modify the Th2-dominated granulomatous phase of schistosomal infection. These viruses induce a strong-specific T cell response, with infiltration of large numbers of specific interferon- $\gamma$-producing CD8+ cells into the liver. The outcome of liver diseases depends on the underlying causes, host immune response and concomitant infections. Co-infection of schistosomiasis with $\mathrm{HBV} / \mathrm{HCV}$ infection causes advanced liver disease and worsens the outcome, especially with higher viral load titers, which increase the mortality rate through an increased incidence of liver cirrhosis and hepatocellular carcinoma. The exposure risk for HBV in patients with HCV and schistosomiasis was two and half times greater than that in $\mathrm{CHC}$ patients without schistosomiasis. Finally, chronic schistosomiasis and $\mathrm{HBV} / \mathrm{HCV}$ co-infection have serious effects on liver pathology. Co-infection accelerates the progression of liver disease and leads to advanced liver diseases and liver failure.
\end{abstract}

Keywords: schistosomiasis, co-infection, HBV, HCV

\section{Introduction}

Schistosomiasis, a parasitic infection, is a public health concern in many countries. Its prevalence is increasing annually; the current infection rate is one in 30 individuals. The WHO reported that at least 206.4 million people all over the world required preventive treatments for schistosomiasis in 2016, of which more than 89 million people have been treated as of right now. ${ }^{1}$

Intestinal schistosomiasis occurs due to Schistosoma mansoni infection. ${ }^{2}$ Chronic S. mansoni infection has been reported in many schistosomiasis cases. The continuous deposition of parasite eggs in human body tissues, particularly the liver, and immunological responses against them are the main causes of chronic hepatosplenic schistosomiasis. ${ }^{3}$ Schistosomiasis, hepatitis B virus (HBV), and hepatitis $\mathrm{C}$ virus (HCV) co-infections are common in countries where schistosomiasis is endemic (endemic areas).

\section{Acute schistosomiasis}

Acute schistosomiasis is the critical primary clinical condition of infection with Schistosoma species. The acute phase is usually presented by persons from 
non-endemic areas (primary infection) who travel to and are exposed to freshwater in endemic areas. The clinical presentation differs according to the severity of the disease, which depends on the patient's immunological response to the parasite's eggs, especially the levels of circulating immune complexes in the patient's blood. ${ }^{4}$

\section{Chronic schistosomiasis}

Chronic schistosomiasis is a chronic inflammatory disease that transitions into a chronic state because of the continuous deposition of the parasite eggs, which are trapped in host tissues. Immunological responses to the eggs lead to granuloma formation, which proceeds to focal areas of fibrosis in the liver. Several years later, the collective effects of chronic tissue irritation and damage could be resulted in liver failure and consequently severe clinical morbidity and mortality. ${ }^{5}$

Hepatosplenic enlargement, portal hypertension and irregular liver surface are the most common hepatosplenic morbidities. The portal hypertension is the end result of the progressive periportal fibrosis. The irregular liver surface and may be associated with esophageal varices and haematemesis. ${ }^{6}$

\section{Immune response to hepatic schistosomiasis}

Cell-mediated immune response and granulomatous formation are the main characters of hepatic schistosomiasis. Immune response results from the allergy to the soluble egg antigen of $S$. mansoni. Moreover, many pathological changes are happened as irreversible fibrosis and, consequently, severe portal hypertension. $^{7}$

Continuously laying of eggs in the liver for approximately 3 weeks leads to activation of immune system and so the hypersensitivity state is developed without ending. ${ }^{8}$

First and foremost, the parasite eggs stimulate the immune reaction and cause a moderate type 1 helper (Th1) response. ${ }^{9}$ Conversely, this usually evolve to a dominant Th2 immune response which developed due to the stimulation of egg-derived antigens then eosinophils were recruited, granuloma was formatted and fibrogenic process of the liver was initiated. ${ }^{10-12}$ Though these pathological changes, which resulted from immunological response, were so important to the infected person, as granuloma formation. They block the hepatotoxic effects of parasite eggs antigen, this reaction may lead to many harmful changes as fibrosis with excessive accumulation of collagen and extracellular matrix proteins in the periportal space. $^{13}$

The cytokines asIL-4, IL-13 and IL-10 with interferon can stimulate helper $\mathrm{T}$ cell-mediated which cause delayed hypersensitivity reaction and granulomatous formation, moreover and interestingly a subset of regulatory $\mathrm{T}$ cells can limit the schistosomal-induced pathology. ${ }^{9,14}$

Also, many different cells were activated as macrophages, hepatic stellate cells and regulatory $\mathrm{T}$ cells. ${ }^{15,16}$ The balance, which happens between both TH1- and TH2-type cytokines, could influence the extent and degree of the pathology and the development and acceleration of fibrosis. ${ }^{17}$ The granulomas contain the parasite eggs of $S$. mansoni and S. japonicum and consequence, the marked portal and peri lobular fibrosis formation are developed. ${ }^{18}$

In addition to the fibrosis formation, there was a critical process that was happened in the lesion. This process is an angiogenesis, which has an important role during granuloma formation and schistosomal portal fibrosis. ${ }^{19,20}$ Likewise, angiogenesis has an interesting mode of action since it has a two-way, participating both in fibrogenesis and in fibrosis degradation. ${ }^{21}$

\section{Schistosomiasis, HBV and HCV co- infection}

Schistosomiasis, HBV and HCV co-infection are reported in many countries especially in countries where schistosomiasis is endemic, such as Egypt. In Egypt, the prevalence of schistosomiasis in patients with HCV infection was approximately $50 \%$ and also other studies reported about 27.3\% of Egyptian patients had both HCV-RNA and schistosomiasis. $^{22,23}$ Additionally, the high prevalence (40.2\%) of HCV and S. mansoni co-infection was reported in wastewater treatment plant workers. ${ }^{24-26}$ However, the prevalence of co-infection of HBV with $S$. mansoni was approximately $19.6-33.0 \%$. Interestingly, the high prevalence was demonstrated in People's Republic of China about $(58.4 \%)$ of the patients had HBV with chronic schistosomiasis. ${ }^{27}$ In addition, the exposure risk for HBV in patients with $\mathrm{HCV}$ and schistosomiasis was two and half times greater than that in $\mathrm{CHC}$ patients without schistosomiasis. $^{23}$

Likewise, in Egypt, the prevalence of occult hepatitis B is elevated in patients with HCV co-infected with schistosomiasis (12.8\%) compared to those without schistosomiasis. The study showed that schistosomiasis was a risk factor for the higher incidence of occult hepatitis B in 
CHC patients because it had a negative effect on HBV replication and helped to hide the virus inside hepatocytes. ${ }^{23}$

Moreover, patients with chronic schistosomiasis have high risk to get HCV and HBV co-infection because of contacting with parenteral treatment for schistosomiasis unsterile syringes during mass campaigns, blood transfusion for anemia, surgical and endoscopic interventions. ${ }^{28-30}$

\section{Immunology of co-infection of schistosomiasis with HBV and HCV}

Immunology of schistosomiasis, HBV and HCV co-infection was demonstrated in patients with hepatosplenic schistosomiasis which was associated with a marked depression in cell-mediated immune responses. ${ }^{31}$

In addition, the effects of the hepatotropic virus coinfection may modify the Th2-dominated granulomatous phase of schistosomal infection. They induce a strongspecific $\mathrm{T}$ cell response, with infiltration of large number of specific interferon (IFN)- $\gamma$-producing $\mathrm{CD} 8+$ cells into the liver (Figure 1).

Moreover, these immunological changes could lead to decrease cytokine levels by downregulation of Th2 cytokine production that are dominant during S. mansoni infection and prompt hepatotoxicity-related morbidity.

The outcome of liver diseases depends on the underlying causes, host immune response and concomitant infections. Co-infection of the schistosomiasis and $\mathrm{HCV}$ infection causes advanced liver disease and worsens the outcome, especially with higher HCV-RNA titers, which increase the mortality rate, through an increase the incidence of liver cirrhosis and hepatocellular carcinoma. ${ }^{32,33}$

Likewise, to evaluate the immune response of the host to $S$. mansoni co-infection with $\mathrm{HCV}$, we have to assess cell-mediated immunity by measure $\mathrm{T}$ helper cells either Th1 or Th2 and the specific subset of memory CD8+ $\mathrm{T}$ cells. Any defect in the immune responses like Serum levels of IFN- $\gamma$, IL-5 and humoral immunity, by measure IgE levels, results in decrease clearance to $\mathrm{HCV}^{34-36}$

Consequently, liver fibrosis, is the dramatic histopathological changes, results from these immunological reactions: hepatic inflammatory responses and viral clearance to $S$. mansoni and HCV co-infected. ${ }^{37}$

\section{Role of chronic schistosomiasis and HBV/HCV co-infection on the liver pathology}

Chronic schistosomiasis and HBV/HCV co-infection can cause a variety of pathological changes in the liver and affect the architecture of hepatocytes arrangement and affect the viability of hepatocytes itself.

Chronic schistosomiasis and HBV co-infection may end with liver cirrhosis to hepatocellular carcinoma in advanced degrees as the co-infection exaggerated the liver pathology more than mono-infection with HBV.

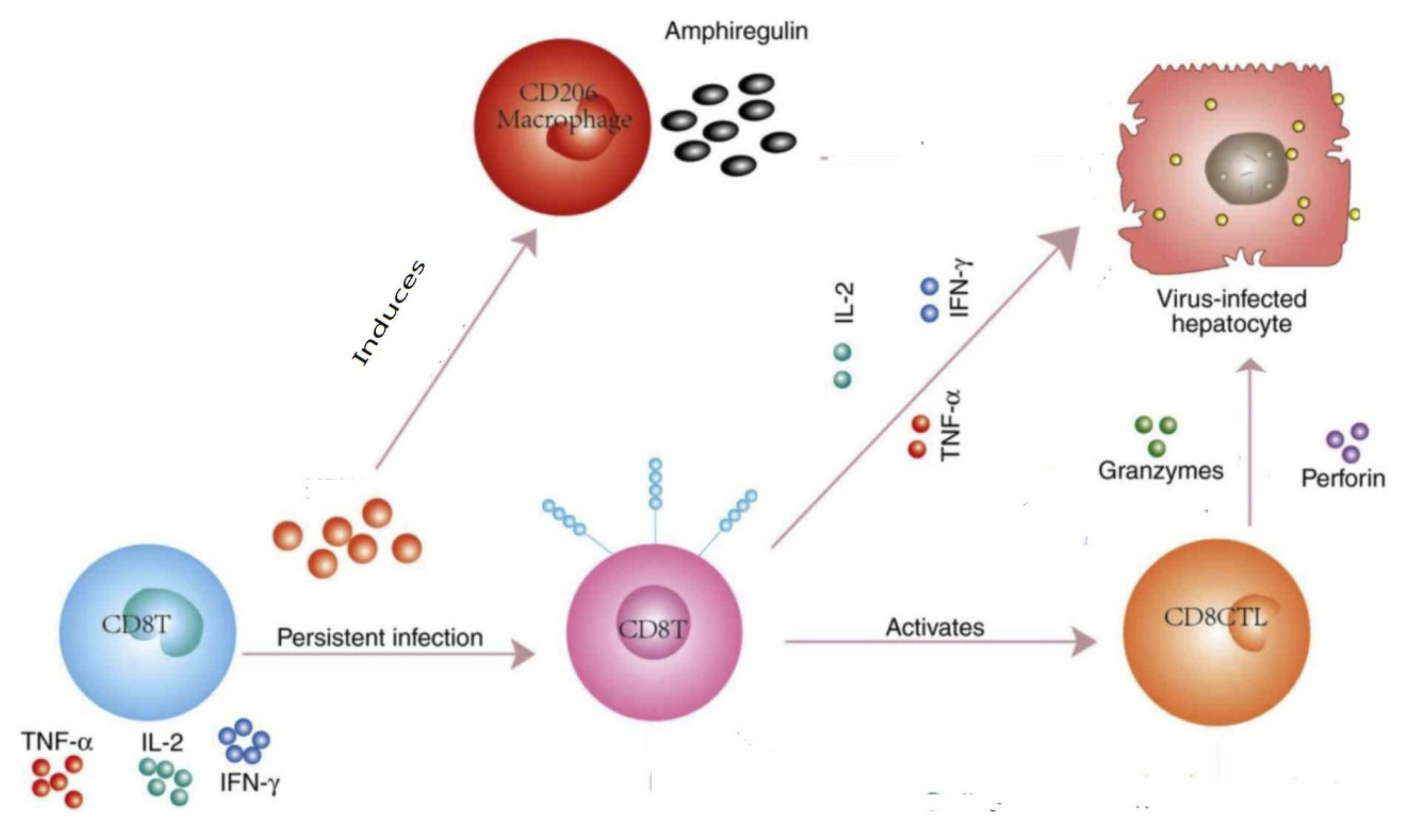

Figure I T cell response with infiltration of large number of specific interferon (IFN)- $\gamma$-producing CD8+ cells into the liver. 
Chronic schistosomiasis is a considerable risk factor for HBV infection and it can facilitate the HBV entrance through change immune response and liver pathology or through the mode of transmission because some schistosomiasis patients may need to blood transfusion. ${ }^{38}$

However, the studies, which were done on the relation of chronic schistosomiasis and HBV co-infection and liver pathology, were discrepancies. Some studies reported there was no association between schistosomiasis and worsening of HBV infection. The antiviral effects of schistosomes related to IFN- $\gamma$ and nitric oxide inhibited HBV replication, ${ }^{39}$ while other studies reported a poor prognosis of HBV when associated with hepatosplenic schistosomiasis. ${ }^{33,37,40}$

In addition, co-infection of HBV with schistosoma prolongs the carriage state and commonly proceeds to chronic hepatitis with extensive cirrhosis. ${ }^{25}$ Chronic schistosomiasis and HBV co-infection could increase the chronicity, morbidity and liver decompensation. ${ }^{36,41-43}$

Similarly, a co-infection of HCV with schistosoma was accompanied with a decrease in the capability to spontaneously resolve the viral infection and frequently leads to rapid fibrosis and also higher mortality. These were explained by the synergistic interactive relationship of schistosoma-HCV with both liver fibrosis as well as with the mortality. ${ }^{25}$ Increased HCV-RNA titers, histological activity, incidence of cirrhosis/hepatocellular carcinoma and higher mortality rates were noticed in patients with co-infection. ${ }^{33}$

Many studies had investigated the degree of severity of liver disease in patients with single viral infection and patients with viral co-infection. The high incidence of liver cirrhosis and liver damage is reported in patients with viral co-infection. ${ }^{44-47}$ The increase in the severity of chronic HBV infection was demonstrated in patients had HCV-Ab.

$\mathrm{HCV}-\mathrm{Ab}$ was detected in $8 \%$ of chronic HBV infection and increased with advanced liver diseases as in patients had HBV-related cirrhosis; HCV-Ab was detected in $10 \%$. Moreover, patients who suffered from HBV-related hepatocellular carcinoma, $\mathrm{HCV}-\mathrm{Ab}$ was detected in $17 \%{ }^{48}$ Likewise, liver cirrhosis was more prevalent in patients with chronic HCV and occult HBV infection with a documented synergistic action of both viruses together in the progression of the liver disease. ${ }^{49}$ Hepatocellular carcinoma was more commonly recognized in co-infected patients $(14 \%)$ in comparing with $2 \%$ and $4 \%$ of chronic hepatitis patients who gained over malignancy on top of chronic $\mathrm{HBV}$ and $\mathrm{HCV}$ infections, respectively. ${ }^{50}$
The primary prevention of $\mathrm{HCV}$ and $\mathrm{HBV}$ infection in endemic country with schistosomiasis is so important and necessary. Insipid of no vaccine presents nowadays for $\mathrm{HCV}$, many procedures have to be done to decrease $\mathrm{HCV}$ transmission in this risky population. HBV vaccine is essential to be used as a routine vaccine for them.

Interestingly, in patients who had schistosomal infection, HBV vaccines can enhance the immune response while on the other hand, reduce the responses to vaccination was reported. ${ }^{31,40,51}$ Hence, further large-scale clinical studies are required to establish the final relation of schistosomiasis and HBV co-infection.

Finally, chronic schistosomiasis and $\mathrm{HBV} / \mathrm{HCV}$ coinfection have serious effects on liver pathology. Co-infection accelerates the progression of liver disease and leads to advanced liver diseases and liver failure.

\section{Disclosure}

The author reports no conflicts of interest in this work.

\section{References}

1. Friedman JF, Olveda RM, Mirochnick MH, Bustinduy AL, Elliott AM. World health assembly. Bull World Health Organ. 2018;96:5965. doi:10.2471/BLT.17.198879

2. Rollinson D, Knopp S, Levitz S, et al. Time to set the agenda for schistosomiasis elimination. Acta Trop. 2013;128(2):423-440. doi:10.1016/j.actatropica.2012.04.013

3. Booth M, Vennervald BJ, Kabatereine NB, et al. Hepatosplenic morbidity in two neighbouring communities in Uganda with high levels of Schistosoma mansoni infection but very different durations of residence. Trans $R$ Soc Trop Med Hyg. 2004;98(2):125-136. doi:10.1016/s0035-9203(03)00018-x

4. Ross AG, Vickers D, Olds GR, Shah SM, McManus DP. Katayama syndrome. Lancet Infect Dis. 2007;7(3):218-224. doi:10.1016/ S1473-3099(07)70053-1

5. King $\mathrm{CH}$, Dangerfield-Cha M. The unacknowledged impact of chronic schistosomiasis. Chronic Illn. 2008;4(1):65-79. doi:10.1177/ 1742395307084407

6. Gasim GI, Bella A, Adam I. Schistosomiasis, hepatitis B and hepatitis C co-infection. Virol J. 2015;12:19. doi:10.1186/s12985-015$0251-2$

7. van der Kleij D, Latz E, Brouwers JF, et al. A novel host-parasite lipid cross-talk. Schistosomal lyso-phosphatidylserine activates tolllike receptor 2 and affects immune polarization. $J$ Biol Chem. 2002;277(50):48122-48129. doi:10.1074/jbc.M206941200

8. Elbaz T, Esmat G. Hepatic and intestinal schistosomiasis: review. $J$ Adv Res. 2013;4(5):445-452. doi:10.1016/j.jare.2012.12.001

9. Wang B, Liang S, Wang Y, et al. Th17 down-regulation is involved in reduced progression of schistosomiasis fibrosis in ICOSL KO mice. PLoS Negl Trop Dis. 2015;9(1):e0003434. doi:10.1371/journal.pntd. 0003434

10. Burke ML, Jones MK, Gobert GN, Li YS, Ellis MK, McManus DP. Immunopathogenesis of human schistosomiasis. Parasite Immunol. 2009;31(4):163-176. doi:10.1111/j.1365-3024.2009.01098.x

11. Colley DG, Secor WE. Immunology of human schistosomiasis. Parasite Immunol. 2014;36(8):347-357. doi:10.1111/pim.12087 
12. Wynn TA, Thompson RW, Cheever AW, Mentink-Kane MM. Immunopathogenesis of schistosomiasis. Immunol Rev. 2004; 201:156-167. doi:10.1111/j.0105-2896.2004.00176.x

13. Morais CN, Souza JR, Melo WG, et al. Cytokine profile associated with chronic and acute human schistosomiasis mansoni. Mem Inst Oswaldo Cruz. 2008;103(6):561-568. doi:10.1590/s0074-027620080 00600009

14. Gieseck RL 3rd, Ramalingam TR, Hart KM, et al. Interleukin-13 activates distinct cellular pathways leading to ductular reaction, steatosis, and fibrosis. Immunity. 2016;45(1):145-158. doi:10.1016/j. immuni.2016.06.009

15. Borthwick LA, Barron L, Hart KM, et al. Macrophages are critical to the maintenance of IL-13-dependent lung inflammation and fibrosis. Mucosal Immunol. 2016;9(1):38-55. doi:10.1038/mi.2015.34

16. Lewis FA, Tucker MS. Schistosomiasis advances in experimental medicine and biology. Adv Exp Med Biol. 2014;766:47-75. doi:10.1007/978-1-4939-0915-5_3

17. Stadecker MJ, Asahi H, Finger E, Hernandez HJ, Rutitzky LI, Sun J. The immunobiology of Th1 polarization in high-pathology schistosomiasis. Immunol Rev. 2004;201:168-179. doi:10.1111/j.0105-2896. 2004.00197.x

18. Shaker Y, Samy N, Ashour E. Hepatobiliary Schistosomiasis. J Clin Transl Hepatol. 2014;2(3):212-216. doi:10.14218/JCTH.2014.00018

19. Andrade ZA, Santana TS. Angiogenesis and schistosomiasis. Mem Inst Oswaldo Cruz. 2010;105(4):436-439. doi:10.1590/s0074-02762 010000400013

20. Baptista AP, Andrade ZA. Angiogenesis and schistosomal granuloma formation. Mem Inst Oswaldo Cruz. 2005;100(2):183-185. doi:10. 1590/s0074-02762005000200012

21. Dematei A, Fernandes R, Soares R, Alves H, Richter J, Botelho MC. Angiogenesis in Schistosoma haematobium-associated urinary bladder cancer APMIS : acta pathologica. microbiologica, et immunologica Scandinavica. 2017;125(12):1056-1062. doi:10.1111/apm.12756

22. Mohd Hanafiah K, Groeger J, Flaxman AD, Wiersma ST. Global epidemiology of hepatitis $\mathrm{C}$ virus infection: new estimates of agespecific antibody to HCV seroprevalence. Hepatology. 2013;57 (4):1333-1342. doi:10.1002/hep.26141

23. Omar HH, Taha SA, Hassan WH, Omar HH. Impact of schistosomiasis on increase incidence of occult hepatitis B in chronic hepatitis C patients in Egypt. J Infect Public Health. 2017;10(6):761-765. doi:10.1016/j.jiph.2016.11.010

24. Abdel-Rahman M, El-Sayed M, El Raziky M, et al. Coinfection with hepatitis $\mathrm{C}$ virus and schistosomiasis: fibrosis and treatment response. World J Gastroenterol. 2013;19(17):2691-2696. doi:10.3748/wjg. v19.i17.2691

25. Abruzzi A, Fried B, Alikhan SB. Coinfection of Schistosoma species with Hepatitis B or Hepatitis C viruses. Adv Parasitol. 2016;91:111231. doi:10.1016/bs.apar.2015.12.003

26. Mazigo HD, Kepha S, Kaatano GM, Kinung'hi SM. Co-infection of Schistosoma mansoni/hepatitis $\mathrm{C}$ virus and their associated factors among adult individuals living in fishing villages, north-western Tanzania. BMC Infect Dis. 2017;17(1):668. doi:10.1186/s12879017-2757-2

27. Du H. [Relationship between advanced schistosomiasis and HBV infection]. Zhongguo Xue Xi Chong Bing Fang Zhi Za Zhi. 2013;25 (1): 115,7 .

28. Muller CP, Edris A, Nour MO, et al. Seroprevalence and risk factors for hepatitis B and C virus infection in Damietta Governorate, Egypt. PloS One. 2014;20(10):605-613.

29. Xaydalasouk K, Strobel M, Buisson Y, Black AP. Seroprevalence and risk factors of hepatitis $\mathrm{B}$ and $\mathrm{C}$ virus infections in female workers of Lao garment factories. PLoS One. 2018;13(7):e0199919.

30. Tozun N, Ozdogan O, Cakaloglu Y, et al. Seroprevalence of hepatitis $\mathrm{B}$ and $\mathrm{C}$ virus infections and risk factors in Turkey: a fieldwork TURHEP study. Clin Microbiol Infect. 2015;21(11):1020-1026. doi:10.1016/j.cmi.2015.06.028
31. Edwards MJ, Buchatska O, Ashton M, Montoya M, Bickle QD, Borrow P. Reciprocal immunomodulation in a schistosome and hepatotropic virus coinfection model. J Immunol. 2005;175(10):62756285. doi:10.4049/jimmunol.175.10.6275

32. Chen SL, Morgan TR. The natural history of hepatitis C virus (HCV) infection. Int J Med Sci. 2006;3(2):47-52. doi:10.7150/ijms.3.47

33. Kamal SM, Rasenack JW, Bianchi L, et al. Acute hepatitis C without and with schistosomiasis: correlation with hepatitis C-specific CD4 (+) T-cell and cytokine response. Gastroenterology. 2001;121 (3):646-656. doi:10.1053/gast.2001.27024

34. Makhlouf LM, Serwah Ael H, Abd El-Hamid Ael D, Hussein EM, Saad RM. INF-gamma, IL-5 and IgE profiles in chronic schistosomiasis mansoni Egyptian patients with or without hepatitis $\mathrm{C}$ infection. J Egypt Soc Parasitol. 2006;36(1):177-196.

35. Elrefaei M, El-Sheikh N, Kamal K, Cao H. HCV-specific CD27CD28- memory $\mathrm{T}$ cells are depleted in hepatitis $\mathrm{C}$ virus and Schistosoma mansoni co-infection. Immunology. 2003;110(4):513518. doi:10.1111/j.1365-2567.2003.01769.x

36. Emam EA, Emam M, Shehata AE, Emara M. Impact of Schistosoma mansoni co-infection on serum profile of interferon-gamma, interleukin-4 and interleukin-10 in patients with chronic hepatitis $\mathrm{C}$ virus infection. Egypt J Immunol. 2006;13(2):33-40.

37. Van-Lume DS, de Albuquerque MF, Souza AI, et al. Association between Schistosomiasis mansoni and hepatitis C: systematic review. Rev Saude Publica. 2013;47(2):414-424. doi:10.1590/S0034-910.201 3047004247

38. Ashir GM, Rabasa AI, Gofama MM, Bukbuk D, Abubakar H, Farouk GA. Study of hepatic functions and prevalence of hepatitis B surface antigenaemia in Nigerian children with human immunodeficiency virus infection. Niger J Med. 2009;18(3):260-262.

39. McClary H, Koch R, Chisari FV, Guidotti LG. Inhibition of hepatitis $\mathrm{B}$ virus replication during schistosoma mansoni infection in transgenic mice. J Exp Med. 2000;192(2):289-294. doi:10.1084/jem.192. 2.289

40. Andrade JR, Silva LD, Guimaraes CM, et al. Chronic hepatitis B and liver schistosomiasis: a deleterious association. Trans $R$ Soc Trop Med Hyg. 2014;108(3):159-164. doi:10.1093/trstmh/tru010

41. Mohamed A, Elsheikh A, Ghandour Z, Al Karawi M. Impact of hepatitis $\mathrm{C}$ virus infection on schistosomal liver disease. Hepatogastroenterology. 1998;45(23):1492-1496.

42. Bahgat MM. Interaction between the neglected tropical disease human schistosomiasis and HCV infection in Egypt: a puzzling relationship. J Clin Transl Hepatol. 2014;2(2):134-139. doi:10.142 18/JCTH.2013.00028

43. Gad A, Tanaka E, Orii K, et al. Relationship between hepatitis C virus infection and schistosomal liver disease: not simply an additive effect. J Gastroenterol. 2001;36(11):753-758.

44. Liaw YF, Chen YC, Sheen IS, Chien RN, Yeh CT, Chu CM. Impact of acute hepatitis $\mathrm{C}$ virus superinfection in patients with chronic hepatitis B virus infection. Gastroenterology. 2004;126(4):10241029. doi:10.1053/j.gastro.2004.01.011

45. Liu CJ, Chuang WL, Lee CM, et al. Peginterferon alfa-2a plus ribavirin for the treatment of dual chronic infection with hepatitis B and C viruses. Gastroenterology. 2009;136(2):496-504.e3. doi:10.10 53/j.gastro.2008.10.049

46. Lee LP, Dai CY, Chuang WL, et al. Comparison of liver histopathology between chronic hepatitis $\mathrm{C}$ patients and chronic hepatitis $\mathrm{B}$ and C-coinfected patients. J Gastroenterol Hepatol. 2007;22(4):515-517. doi:10.1111/j.1440-1746.2006.04547.x

47. Liu CJ, Liou JM, Chen DS, Chen PJ. Natural course and treatment of dual hepatitis B virus and hepatitis $\mathrm{C}$ virus infections. J Formos Med Assoc. 2005;104(11):783-791.

48. Chen DS, Kuo GC, Sung JL, et al. Hepatitis C virus infection in an area hyperendemic for hepatitis $\mathrm{B}$ and chronic liver disease: the Taiwan experience. J Infect Dis. 1990;162(4):817-822. doi:10.1093/ infdis/162.4.817 
49. Sagnelli E, Coppola N, Scolastico C, Mogavero AR, Filippini P, Piccinino F. HCV genotype and "silent" HBV coinfection: two main risk factors for a more severe liver disease. J Med Virol. 2001;64(3):350-355.

50. Zampino R, Pisaturo MA, Cirillo G, et al. Hepatocellular carcinoma in chronic HBV-HCV co-infection is correlated to fibrosis and disease duration. Ann Hepatol. 2015;14(1):75-82.
51. Lundy SK, Lukacs NW. Chronic schistosome infection leads to modulation of granuloma formation and systemic immune suppression. Front Immunol. 2013;4:39. doi:10.3389/fimmu.2013.00 039

\section{Publish your work in this journal}

Hepatic Medicine: Evidence and Research is an international, peerreviewed, open access journal covering all aspects of adult and pediatric hepatology in the clinic and laboratory including the following topics: Pathology, pathophysiology of hepatic disease; Investigation and treatment of hepatic disease; Pharmacology of drugs used for the treatment of hepatic disease. Issues of patient safety and quality of care will also be considered. The manuscript management system is completely online and includes a very quick and fair peer-review system, which is all easy to use. Visit http://www.dovepress.com/ testimonials.php to read real quotes from published authors.

Submit your manuscript here: https://www.dovepress.com/hepatic-medicine-evidence-and-research-journal 